\title{
Os gêneros Brymela, Callicostella, Crossomitrium, Cyclodictyon, Hookeriopsis, Hypnella e Trachyxiphyum (Pilotrichaceae, Bryophyta) no Estado do Rio de Janeiro, Brasil ${ }^{1}$
}

\author{
Thaís de Freitas $\operatorname{Vaz}^{2,4}$ e Denise Pinheiro da Costa ${ }^{3}$
}

Recebido em 12/01/2006. Aceito em 28/06/2006

\begin{abstract}
RESUMO - (Os gêneros Brymela, Callicostella, Crossomitrium, Cyclodictyon, Hookeriopsis, Hypnella e Trachyxiphium (Pilotrichaceae, Bryophyta) no Estado do Rio de Janeiro, Brasil). No Estado do Rio de Janeiro a família Pilotrichaceae está representada por 35 espécies, compreendidas em 11 gêneros. O trabalho é parte dos estudos realizados com a família no Estado, tratando de 18 espécies pertencentes aos gêneros Brymela Crosby \& B.H. Allen, Callicostella (Müll. Hal.) Mitt., Crossomitrium Müll. Hal., Cyclodictyon Mitt., Hookeriopsis (Besch.) A. Jaeger, Hypnella (Müll. Hal.) A. Jaeger e Trachyxiphium W.R. Buck. São apresentados para cada espécie descrições diagnósticas, ilustrações, comentários, distribuição geográfica e o status de conservação.
\end{abstract}

Palavras-chave: briófitas, musgos pleurocárpicos, taxonomia, Mata Atlântica

\begin{abstract}
The genera Brymela, Callicostella, Crossomitrium, Cyclodictyon, Hookeriopsis, Hypnella and Trachyxiphium (Pilotrichaceae, Bryophyta) in Rio de Janeiro State, Brazil). Pilotrichaceae is represented in Rio de Janeiro State by 35 species and 11 genera. This work is part of a larger study on the family in the state, and presents a taxonomic treatment of 18 species in the genera Brymela Crosby \& B.H. Allen, Callicostella (Müll. Hal.) Mitt., Crossomitrium Müll. Hal., Cyclodictyon Mitt., Hookeriopsis (Besch.) A. Jaeger, Hypnella (Müll. Hal.) A. Jaeger and Trachyxiphium W.R. Buck. Descriptions, illustrations, comments, distribution, and conservation status for each species are presented.
\end{abstract}

Key words: bryophytes, pleurocarpic mosses, taxonomy, Atlantic rain forest

\section{Introdução}

A família Pilotrichaceae está representada no Brasil por 14 gêneros e ca. 140 espécies (Yano 1996) e na América Tropical, onde é bastante diversificada especialmente nas regiões úmidas, por 21 gêneros e ca. 200 espécies (Gradstein et al. 2001). Caracteriza-se por apresentar os ramos primários rastejantes e os secundários ascendentes ou eretos, costa dupla (ausente somente em Crossomitrium), geralmente bem desenvolvida, presença de hialoderme no caulídio da maior parte das espécies, filídios frequentemente complanados, células variando de isodiamétricas a lineares, lisas ou papilosas, sendo as alares não diferenciadas, e caliptra geralmente pilosa (Buck 1998; Gradstein et al. 2001). Outras características importantes para diversas espécies são a diferenciação entre os filídios laterais e dorsais/ventrais, sendo os dorsais/ventrais simétricos e os laterais assimétricos e a presença de seta ornamentada, que pode ser rugosa, papilosa ou espinhosa.

As publicações que tratam dos táxons de Pilotrichaceae (Sehnem 1979; Crosby et al. 1985; Allen 1986, 1990; Schäfer-Verwimp 1989; 1992; Costa 1995; Oliveira-e-Silva \& Yano 1998; 2000) são escassas e dispersas, se limitando a levantamentos florísticos de determinadas áreas e revisões taxonômicas de poucos gêneros. Não existe, até o momento, um trabalho que una informações sobre as espécies brasileiras e que auxilie a identificação e delimitação dos seus táxons. Isto evidencia a necessidade urgente da elaboração de um estudo taxonômico para esta importante família de musgos no sudeste do país.

Este trabalho é parte de uma série de estudos realizados sobre Pilotrichaceae no Estado do Rio de Janeiro, tratando espécies dos gêneros Brymela, Callicostella, Crossomitrium, Cyclodictyon, Hookeriopsis, Hypnella e Trachyxiphyum, e objetiva

\footnotetext{
1 Parte da Dissertação de Mestrado da primeira Autora

2 Univerisidade Federal do Rio de Janeiro, Museu Nacional, Quinta da Boa Vista, 20940-040 São Cristóvão, RJ, Brasil

3 Instituto de Pesquisas Jardim Botânico do Rio de Janeiro, Rua Pacheco Leão 915, 22460-030 Rio de Janeiro, RJ, Brasil

4 Autor para correspondência: celvaz@terra.com.br
} 
fornecer um guia taxonômico que facilite a identificação e delimitação de seus táxons no Estado, ampliando o conhecimento desta família no país. Este estudo também representa uma contribuição ao Projeto Flora do Estado do Rio de Janeiro.

\section{Material e métodos}

Inicialmente foi elaborada uma lista preliminar com 12 gêneros e 64 espécies da família Pilotrichaceae citadas para o Estado do Rio de Janeiro, com base nas seguintes publicações: Hornschuch (1840), Müller (1856; 1859; 1898; 1900; 1901), Hampe (1872; 1874a,b; 1877; 1879), Hampe \& Geheeb (1881), Brotherus (1894; 1895a,b), Dúsen (1903), Herzog (1927), Wijk et al. (1959-1969), Schiffner \& Arnell (1964), Yano (1981; 1989; 1995), Schäfer-Verwimp (1989; 1992), Costa (1995), Oliveira-e-Silva \& Yano (1998; 2000).

Posteriormente, foi realizada a revisão nomenclatural dos táxons com base nos trabalhos de Allen (1986), Buck (1987; 1998), Crosby et al. (1999), além de exame de material de herbários nacionais e estrangeiros (Botanischer Garten und Botanisches Museum Berlin-Dahlen - B, British Museum - BM, Herbarium Haussknecht - JE, Instituto Anchietano de Pesquisas - PACA, Instituto de Pesquisas Jardim Botânico do Rio de Janeiro - RB, Missouri Botanical Garden - MO, Museu Nacional - R e Universidade do Estado do Rio de Janeiro - HRJ).

A chave para a identificação dos gêneros e de espécies de Pilotrichaceae foi elaborada com base na literatura e no exame de 50 exemplares das coleções dos herbários acima citados.
A classificação adotada neste trabalho segue a proposta por Buck \& Goffinet (2000). Os termos utilizados nas descrições e chaves foram baseados no Glossarium Polyglottum Bryologiae (Magill 1990).

São apresentadas chaves de identificação, descrições diagnósticas, distribuição, status de conservação e ilustrações para os táxons. Os dados apresentados foram baseados nos materiais de diferentes herbários, bem como nos dados da literatura.

Para a descrição dos táxons, foram consideradas somente as características diagnósticas, tendo como base dados de literatura e de material de herbário. Quando o material estava estéril, a descrição do esporófito foi complementada com dados da literatura.

Os dados de distribuição geográfica e variação altitudinal, no Rio de Janeiro e no Brasil, e status de conservação no Estado, foram retirados de Costa et al. (2005), complementados com dados do material examinado.

\section{Resultados}

Após a revisão da lista de espécies e estudo dos tipos, ocorreu uma redução de $39 \%$ no número total de táxons da família citados para o Estado do Rio de Janeiro. São reconhecidos, nesse trabalho, para a família Pilotrichaceae no Estado do Rio de Janeiro 11 gêneros e 35 espécies e tratadas as 18 espécies dos gêneros Brymela, Callicostella, Crossomitrium, Cyclodictyon, Hookeriopsis, Hypnella e Trachyxiphyum ocorrentes no Estado, apresentados três novos sinônimos e excluídas 11 espécies do estudo.

Chave para identificação dos gêneros Brymela, Callicostella, Crossomitrium, Cyclodictyon, Hookeriopsis, Hypnella e Trachyxiphium

1. Filídios sem costa Crossomitrium

1. Filídios com costa dupla

2. Filídios bordeados por células mais alongadas que as da lâmina Cyclodictyon

2. Filídios não bordeados por células mais alongadas que as da lâmina

3. Células do filídio lisas

4. Costa conspícua alcançando de 3/4-9/10 do compr. do filídio, podendo ser denteada; células da lâmina isodiamétricas $( \pm 1: 1-2)$.................................................. Callicostella (em parte)

4. Costa inconspícua alcançando $1 / 2$ do compr. do filídio, nunca denteada; células da lâmina lineares

Hookeriopsis

3. Células do filídio papilosas

5. Células do filídio com papilas sobre o lúmen

6. Células isodiamétricas, com 1-2 papilas sobre o lúmen Callicostella (em parte)

6. Células longo-romboidais, com 2-5(-7) papilas em série sobre o lúmen Hypnella 
5. Células do filídio com papilas no ângulo apical

7. Filídios lanceolados, margem com dentes geralmente bífidos, inflados

7. Filídios falcado-lanceolados, margem com dentes simples, não inflados

Trachyxiphium Brymela

\section{Brymela Crosby \& B.H. Allen}

Gametófito robusto, caulídio em secção transversal sem hialoderme, filídios com margem não diferenciada, serreada, formada por dentes simples, não inflados, costa alcançando mais da $1 / 2$ do compr. do filídio, células da lâmina com papila no ângulo apical.

Gênero neotropical com ca. 12-13 espécies, ocorrendo sobre troncos em decomposição, húmus, rochas, troncos de arbustos e lianas; desde florestas de terra baixa a sub-montana, raramente alcançando as alto montana, entre 100-2.000(-3.400) m (Gradstein et al. 2001). No Rio de Janeiro está representado por uma espécie, ocorrendo sobre rocha, ca. $1.100 \mathrm{~m}$.

1.1 Brymela fluminensis (Hampe) W.R. Buck, Brittonia 39: 217. 1987. Tipo. Brasil, Rio de Janeiro, Glaziou 11727 (isótipo NY).

Fig. 1-8

Trachyxiphium drepanophyllum (Geh. \& Hampe) Schäf.-Verw., J. Hattori Bot. Lab. 67: 318. 1989. Tipo. Brasil, São Paulo, Apiaí, VI-1879, Puiggari 179, 192 (síntipos BM), comb. inval.

Gametófito verde-amarelado, caulídio rastejante com ramos ascendentes ou irregularmente ramificado; filídios falcado-lanceolados; ápice longo-acuminado; margem serreada acima e sinuada a inteira em direção à base, com dentes simples; costa conspícua e dupla, alcançando $\pm 4 / 5$ do compr., com ápice paralelo, denteado a cristado na superfície dorsal do filídio; células com papila no ângulo apical, no ápice longoromboidais, na região mediana lineares e na basal retangulares, com poucas papilas. Filídios periqueciais lanceolados, com margem serreada e costa dupla alcançando 3/5 do seu compr. Esporófito com seta longa $( \pm 2,5 \mathrm{~cm})$, lisa, cápsula ereta. Caliptra não observada.
Material examinado: BRASIL. Rio de Janeiro: Itatiaia, Cachoeira do Maromba, 27/V/1927, Occhini s.n. (RB 156664).

Em 1989, Schäfer-Verwimp propôs uma nova combinação para Hookeriopsis drepanophylla (Geh. \& Hampe) Broth., cujo basiônimo é Hookeria drepanophylla Geh. \& Hampe, transferindo-o para Trachyxiphium drepanophyllum (Geh. \& Hampe) Schäf.-Verw. Entretanto, Buck em 1987, já havia sinonimizado Hookeria drepanophylla com Brymela fluminensis, o que torna essa combinação de ShäferVerwimp (1989) inválida.

Espécie endêmica do Brasil, ocorrendo nos Estados do ES, RJ, SP, PR e RS, entre 800-2.500 m. No Rio de Janeiro, ocorre no Município de Itatiaia, sobre rocha, ca. 1.100 m. Status de conservação: Baixo Risco (LR).

\section{Callicostella (Müll. Hal.) Mitt. nom. cons.}

Gametófito irregularmente ramificado, caulídio em secção transversal sem hialoderme, filídios frouxamente complanados, margem não diferenciada, serrulada a serreada, geralmente com dentes inflados, costa dupla, ultrapassando 3/4 do compr. do filídio, células lisas ou com 1(-2) papilas, as apicais em geral isodiamétricas (1-2:1).

Apresenta aproximadamente 60 espécies no Neotrópico, embora Gradstein et al. (2001) comentem que, após uma revisão este número poderá ser reduzido para 30. As espécies ocorrem sobre solo, troncos caídos e rochas, freqüentemente associadas a córregos, nas florestas de terra baixa a sub-montana, entre 0-1.200(-2.400) m (Gradstein et al. 2001). No Rio de Janeiro o gênero está representado por sete espécies, ocorrendo sobre rocha, tronco em decomposição, frequientemente associadas a cursos d'água, entre $0-1.300 \mathrm{~m}$.

Chave para as espécies de Callicostella

1. Células do filídio lisas

2. Ápice do filídio arredondado; costa no ápice convergente; seta lisa

2.4. C. merkelii

2. Ápice do filídio obtuso a apiculado, podendo variar para agudo; costa no ápice paralela; seta rugosa 2.7. C. rufescens

1. Células do filídio papilosas, papilas sobre o lúmen

3. Filídio com margem sem dentes inflados; costa com ápice liso 2.3. C. martiana

3. Filídio com margem com dentes inflados; costa com ápice denteado 
4. Filídios laterais e dorsais/ventrais diferenciados

5. Costa paralela no ápice; margem na região mediana do filídio levemente serrulada; células da lâmina lisas, raramente papilosas; seta rugosa 2.6. C. pallida

5. Costa convergente no ápice; margem na região mediana do filídio serreada; células da lâmina papilosas; seta lisa 2.1. C. apophysata

4. Filídios laterais e dorsais/ventrais não diferenciados

6. Filídios ovados a oblongo-ovados; costa alcançando \pm 9/10 do compr. do filídio, com ápice denteado por 2-4(-6) dentes 2.2. C. depressa

6. Filídios oblongos; costa alcançando $\pm 5 / 6$ do compr. do filídio, com ápice denteado por 1-2 dentes 2.5. C. microcarpa

2.1 Callicostella apophysata (Hampe) A. Jaeger, Ber. Thätigk. St. Gallischen Naturwiss. Ges. 1875-76: 352. 1877. Tipo. Brasil, Rio de Janeiro, Glaziou, ex Herb. Hampe no. 7199 (holótipo BM!)

Fig. 9-15

Gametófito irregularmente ramificado; filídios diferenciados, os laterais oblongos e os dorsais/ventrais ovados; ápice arredondado a truncado no filídio lateral e obtuso no dorsal/ventral; margem serreada, com dentes inflados; costa conspícua e dupla, convergindo abruptamente, quase atingindo o ápice $(+9 / 10$ do compr.), a partir do terço superior fortemente denteada na superfície dorsal; células apicais e medianas arredondadas a quadráticas, mais ou menos isodiamétricas, com uma papila sobre o lúmen, células na base retangulares e lisas. Esporófito com seta lisa, cápsula horizontal a pendente, com apófise, caliptra mitrada e lisa.

Material examinado: BRASIL. Rio de Janeiro: Magé, Distrito de Santo Aleixo, RPPN El Nagual, 4/VIII/2005, Santos \& Costa 333 (RB); ibid, alto do morro, 5/VIII/2005, Santos \& Costa 363 (RB).

Endêmica do Brasil, ocorrendo nos Estados de GO e RJ, em elevações próximas ao nível do mar. No Estado do Rio de Janeiro foi citada sem localidade para o Município do Rio de Janeiro por Hampe (1874a). Nesse estudo é citada para Magé, ao nível do mar. Status de conservação: Dados Deficientes (DD).

2.2 Callicostella depressa (Hedw.) A. Jaeger, Ber. Thätigk. St. Gallischen Naturwiss. Ges. 1875-76: 352. 1877. Tipo. Jamaica, 1783-1787, Swartz s.n. (holótipo NY).

Fig. 16-22

Gametófito irregularmente ramificado; filídios ovados, oblongo-ovados a oblongo-lanceolados; ápice arredondado ou cuspidado; margem irregularmente serreada acima, com dentes inflados, sinuada em direção a base; costa conspícua e dupla, quase atingindo o ápice ( $\pm 9 / 10$ do compr.), com ápice fortemente denteado (2-6 dentes); células apicais e medianas ovais, isodiamétricas $( \pm 1-2: 1)$, com 1(-2) papilas sobre o lúmen, lisas e retangulares em direção à base. Esporófito com seta lisa, cápsula horizontal a pendente. Caliptra não observada.

Material examinado: BRASIL. Rio de Janeiro: Rio de Janeiro, Parque Nacional da Tijuca, Rio dos Macacos, 13/IX/1984, Costa 114 (RB).

Material adicional: BRASIL. Acre: Reserva Indígena da Praia do Carapanã, colocação Macuripe, 20/XI/1995, Costa 2708 et al. (RB); Tarauacá, Alto Juruá, 17/XI/1995, Costa 2594 et al. (RB).

Callicostella depressa se diferencia das demais espécies do Estado pelo ápice da costa, que apresenta um aglomerado de 2-4(-6) dentes. Segundo Buck (1998), pode ser confundida com as formas de C. pallida (Hornsch.) Ångstr. que apresentam seta lisa. No material de $C$. pallida examinado, o ápice do filídio é mais arredondado e não cuspidado, como em C. depressa. Segundo Buck (1998), a caliptra é mitrada, rugosa no ápice e lisa em direção à base.

Apresenta distribuição neotropical e no Brasil ocorre nos Estados do RR, PA, AM, AC, RO, AL, MT e RJ entre 0-100 m. No Rio de Janeiro ocorre no Município do Rio de Janeiro, ao nível do mar, geralmente sobre tronco caído em florestas úmidas, e raramente sobre solo e rochas. Status de conservação: Baixo Risco (LR).

2.3 Callicostella martiana (Hornsch.) A. Jaeger, Ber. Thätigk. St. Gallischen Naturwiss. Ges. 1875-76: 351. 1877. Tipo. Brasil, Bahia, rio São Francisco, próximo a Juazeiro, Martius s.n. (holótipo BM).

Fig. 23-28

Gametófito irregularmente ramificado; filídios oblongos a ovados; ápice arredondado a obtuso ou levemente apiculado; margem irregularmente serreada a serrulada no ápice, sem dentes inflados, serrulada 


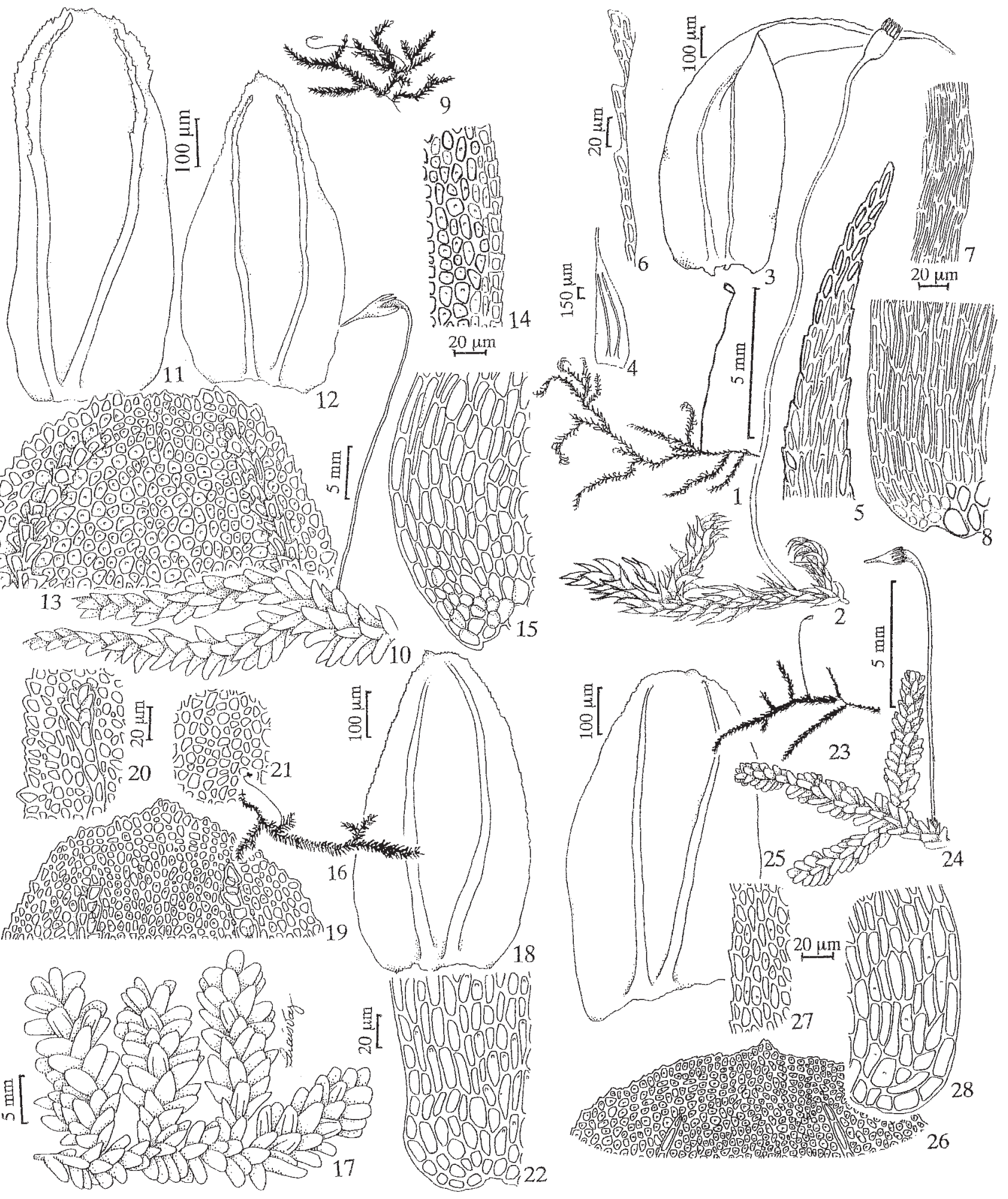

Figuras 1-8. Brymela fluminensis (Hampe) W.R. Buck. 1. Hábito. 2. Detalhe do gametófito com esporófito. 3. Filídio. 4. Forma do filídio. 5. Ápice do filídio. 6. Detalhe da costa no ápice. 7. Células da margem do filídio. 8. Células da base do filídio. Figuras 9-15. Callicostella apophysata (Hampe) A. Jaeger. 9. Hábito. 10. Detalhe do gametófito com esporófito. 11. Filídio lateral. 12. Filídio dorsal. 13. Ápice do filídio com detalhe do ápice da costa. 14. Células da margem do filídio. 15. Células da base do filídio. Figuras 16-22. Callicostella depressa (Hedw.) A. Jaeger. 16. Hábito. 17. Detalhe do gametófito. 18. Filídio. 19. Ápice do filídio. 20. Detalhe da costa no ápice. 21. Células medianas do filídio. 22. Células da base do filídio. Figuras 23-28. Callicostella martiana (Hornsch.) A. Jaeger. 23. Hábito. 24. Detalhe do gametófito com esportófito. 25. Filídio. 26. Ápice do filídio. 27. Células da margem do filídio. 28. Células da base do filídio. 
em direção à base; costa conspícua e dupla, convergente no extremo ápice, quase o atingindo (+9/10), com ápice liso; células apicais e medianas isodiamétricas a quadradas, com uma papila, tornando-se retangulares e lisas em direção à base. Esporófito com seta lisa, cápsula horizontal a inclinada. Caliptra pilosa na base.

Material examinado: BRASIL. Rio de Janeiro: Parati, estrada para Parati-Mirim, 22/X/1990, Costa 1315 et al. (RB).

Espécie endêmica do Brasil, ocorrendo na região sul e nos Estados da BA, MT, MG e RJ, entre 0-1.000 m. No Rio de Janeiro ocorre no Município de Parati, sobre tronco caído, rocha ou solo, junto a cursos d’água, ao nível do mar. Status de conservação: Baixo Risco (LR).

2.4 Callicostella merkelii (Hornsch.) A. Jaeger, Ber. Thätigk. St. Gallischen Naturwiss. Ges. 1875-76: 356. 1877. Tipo. Brasil, Rio de Janeiro, Merkel s.n. (holótipo BM).

Fig. 29-34

Gametófito irregularmente e densamente ramificado; filídios oblongos a oblongo-ovados; ápice arredondado a arredondado-apiculado, freqüentemente retuso; margem regularmente serrulada na metade superior, com alguns dentes inflados; costa conspícua e dupla, divergente na base, e na porção superior convergente ou menos freqüentemente paralela, quase atingindo a margem superior, com ápice denteado; células apicais e medianas isodiamétricas, lisas ou, mais raramente, apresentando uma pequena papila, as basais retangulares, com uma papila. Esporófito com seta lisa, cápsula horizontal a pendente. Caliptra não observada.

Material examinado: BRASIL. Rio de Janeiro: Angra dos Reis, Ilha Grande, caminho para Parnaioca, 100 m, 16/V/1995, Oliveira-e-Silva 4161 (HRJ); Mangaratiba, Km 54 da Rodovia Rio-Santos, Reserva Ecológica Rio das Pedras, 5/VIII/1993, Oliveira-eSilva 596 (HRJ); ibid. Praia do Mangue, 22/VIII/1994, Oliveira-e-Silva 2074 (HRJ).

Segundo Florschütz-de Waard (1986), a caliptra é rugosa no ápice.

Apresenta distribuição neotropical, ocorrendo no Brasil nos Estados do RR, PA, AC, MG, RJ, SP e SC, entre 0-800 m. No Rio de Janeiro ocorre nos Municípios de Angra dos Reis, Casimiro de Abreu, Mangaratiba, Niterói, Parati e Rio de Janeiro, sobre solo, rochas, geralmente associada a cursos d'água, entre 0-500 m. Status de conservação: Baixo Risco (LR).
2.5 Callicostella microcarpa Ångstr., Öfvers. Förh. Kongl. Svenska Vetensk.-Akad. 33(4): 27. 1876. Tipo. Brasil, Minas Gerais, Martius s.n. (holótipo BM).

Fig. 35-40

Gametófito irregularmente ramificado; filídios pequenos ( $\pm 0,8 \mathrm{~mm}$ de compr.), oblongos; ápice obtuso a apiculado; margem irregularmente serreada, com dentes inflados no ápice; costa conspícua e dupla, paralela a convergente no ápice, atingindo $\pm 5 / 6$ do compr. do filídio, com ápice denteado (1-2 dentes); células apicais e medianas ovais a isodiamétricas, apresentando uma papila sobre o lúmen, tornando-se retangulares e lisas em direção à base. Esporófito com seta lisa, cápsula horizontal. Caliptra não observada.

Material examinado: BRASIL. Rio de Janeiro: Nova Friburgo, Mata do Registro, 5/VII/1927, GUA 11640 M. Bandeira (HRJ).

Esta espécie se distingue das demais pelo seu gametófito muito reduzido, apresentando entre 0,8-1,0 $\mathrm{mm}$ de largura, com filídios variando entre 0,5-0,8 $\mathrm{mm}$ de compr. e 0,17-0,29 $\mathrm{mm}$ de largura, enquanto que nas demais espécies estudadas o gametófito varia entre 1,2-2,2 mm de largura e os filídios entre 0,8-1,0 mm de compr. e 0,3-0,48 mm de largura.

Apresenta distribuição neotropical, ocorrendo no Brasil nos Estados do RR, PA, AM, MG, RJ, SP e SC, entre 0-800 m. No Rio de Janeiro, ocorre nos Municípios de Nova Friburgo e Rio de Janeiro, ca. 850 m. Status de conservação: Baixo Risco (LR).

2.6 Callicostella pallida (Hornsch.) Ångstr., Öfvers. Förh. Kongl. Svenska Vetensk.-Akad. 33(4): 27.1876. Tipo. Brasil, afluente secundário do rio Amazonas, Martius s.n.; Minas Gerais, Vila Rica, Martius s.n.; Rio de Janeiro, Tijuca, Beyrich et Olfers s.n. (síntipos $\mathrm{BM})$.

Fig. 41-50

Gametófito irregularmente ramificado; filídios diferenciados, os laterais assimétricos e ventrais/ dorsais simétricos, oblongos a oblongo-ovados; ápice arredondado nos laterais e frequientemente apiculado nos ventrais/dorsais; margem irregularmente serreada a serrulada, com dentes inflados no ápice, podendo ser ligeiramente diferenciada com células mais alongadas; costa conspícua e dupla, paralela no ápice, quase atingindo a margem superior, denteado; células apicais e medianas isodiamétricas a curto-romboidais, podendo apresentar uma papila sobre o lúmen, tornando-se retangulares e lisas na base. Esporófito com seta rugosa, cápsula inclinada a pendente. Caliptra não observada. 
Material examinado: BRASIL. Rio de Janeiro: Mangaratiba, Km 54 da Rodovia Rio-Santos, Reserva Ecológica Rio das Pedras, 11/III/1993, Oliveira-eSilva 181-A (HRJ); ibid. 14/IV/1993, Oliveira-eSilva 365 (HRJ); ibid. 15/IV/1993, Oliveira-e-Silva 364 (HRJ); Rio de Janeiro, Parque Nacional da Tijuca, 10/IX/1983, Costa 33 (RB).

Segundo Buck (1998), a caliptra é mitrada e rugosa no ápice.

Todas as características observadas no material estudado coincidem com a descrição de Buck (1998), exceto pela seta, que segundo este autor é lisa, enquanto que no material estudado é rugosa.

Apresenta distribuição neotropical, com ampla ocorrência no Brasil (RR, AP, PA, AM, AC, RO, PE, AL, SE, BA, GO, MT, MS, regiões sudeste e sul), entre 0-1.300 m. No Rio de Janeiro, ocorre nos Municípios de Angra dos Reis, Casimiro de Abreu, Itatiaia, Mangaratiba, Niterói, Nova Friburgo, Parati, Rio de Janeiro e Teresópolis, sobre troncos caídos, rochas, freqüentemente associadas a cursos d'água, entre 0-1.300 m. Status de conservação: Baixo Risco (LR).

2.7 Callicostella rufescens (Mitt.) A. Jaeger, Ber. Thätigk. St. Gallischen Naturwiss. Ges. 1875-76: 355. 1877. Tipo. Brasil, Pará, rio Amazonas, Spruce 629 (holótipo BM).

Fig. 51-59

Gametófito irregularmente ramificado; filídios oblongos a ovados; ápice obtuso a apiculado, agudo ou mucronado, podendo variar no mesmo indivíduo ou entre indivíduos da mesma população; margem irregularmente serreada próximo ao ápice, com dentes inflados, serrulada ou duplo-serreada em direção à base; costa conspícua e dupla, avermelhada nos filídios mais antigos, atingindo 3/4-7/8 do compr. do filídio, com ápice liso ou com dentes; células apicais e medianas menores que as basais, curto-romboidais a isodimétricas, raramente apresentando papilas, células basais retangulares, lisas. Esporófito com seta rugosa, cápsula horizontal a pendente. Caliptra não observada.

Material examinado: BRASIL. Rio de Janeiro: Parati, trilha do Corisco até Rasa, 13/XI/1990, Costa 1407 et al. (RB).

Florschütz-de-Waard (1986) cita a seta como papilosa e a caliptra como escabrosa no ápice, profundamente laciniada na base, porém no material examinado a seta apresentou-se rugosa e a caliptra não foi observada. Esse autor também comenta sobre a variação do ápice do filídio, que pode ser truncado, apiculado, curto-acuminado ou longo-acuminado, e do tamanho das células apicais, que variam com a forma do ápice. Essa variação também foi observada tanto no ápice do filídio, quanto nas células apicais, no material do herbário RB.

Apresenta distribuição neotropical, ocorrendo de forma descontínua no Brasil, nos Estados do PA, AM e RJ, entre 0-200 m. Essa distribuição, possivelmente, é resultado da falta de coletas nas regiões intermediárias. No Rio de Janeiro ocorre no Município de Parati, sobre rocha, ao nível do mar. Status de conservação: Dados Deficientes (DD).

Espécie excluída do estudo:

Callicostella paulensis Broth. - Embora o material do herbário RB identificado por Brotherus seja muito similar a $C$. microcarpa e possivelmente represente um sinônimo deste, a sinonimização não pôde ser realizada, uma vez que não foi possível examinar o material tipo, depositado no Herbário de Helsinki $(\mathrm{H})$.

\section{Crossomitrium Müll Hal.}

Gametófito densamente e irregularmente ramificado, caulídio em secção transversal sem hialoderme, com propágulos na superfície ventral ou nas extremidades de ramos modificados, filídios serrulados, com margem não diferenciada, sem costa (característica que distingue o gênero dos demais de Pilotrichaceae). Esporófitos não são muito comuns, sendo conhecidos somente para quatro espécies e, como conseqüência, o principal meio de reprodução parece ser os propágulos assexuais (Allen 1990; Gradstein et al. 2001). A presença de propágulos representa uma característica taxonômica importante para o reconhecimento do gênero (Allen 1990).

O gênero apresenta seis espécies no Neotrópico, ocorrendo geralmente como epífilas, também sobre ramos e troncos de arbustos, em florestas de terra baixa a sub-montana, entre 0-2.000 m (Gradstein et al. 2001). No Rio de Janeiro está representado apenas por Crossomitrium patrisiae, que ocorre como epífila e ocasionalmente sobre tronco de árvores, entre 0-800 m, predominando ao nível do mar.

3.1 Crossomitrium patrisiae (Brid.) Müll. Hal., Linnaea 38. 612. 1874. Tipo. Guiana Francesa, Fée s.n. (holótipo B).

Fig. 60-66

Gametófito amarelado, verde-claro brilhante ou castanho-esverdeado, com ramificação irregular; 


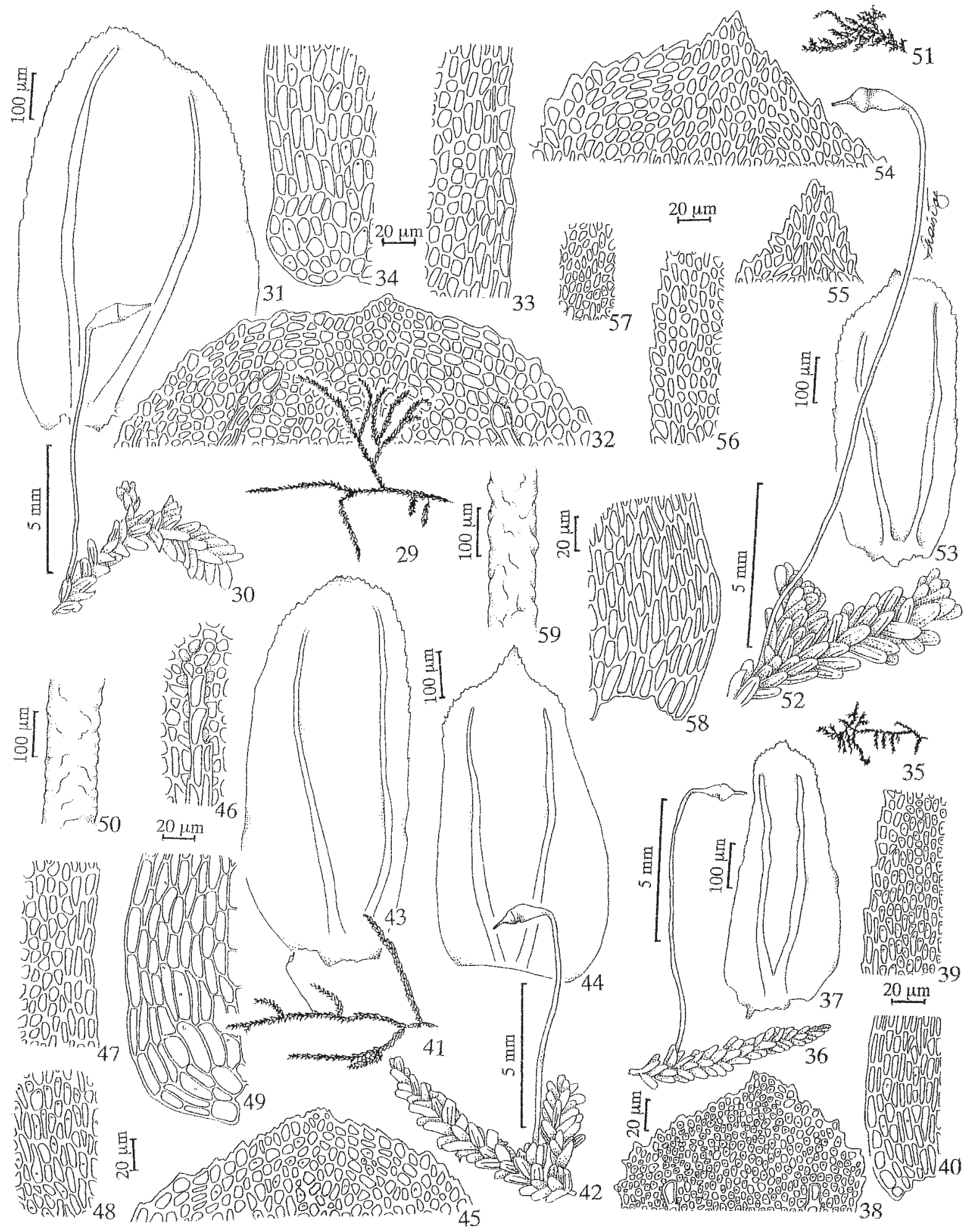

Figuras 29-34. Callicostella merkelii (Hornsch.) A. Jaeger. 29. Hábito. 30. Detalhe do gametófito com esporófito. 31. Filídio. 32. Ápice do filídio. 33. Células da margem do filídio. 34. Células da base do filídio. Figuras 35-40. Callicostella microcarpa Ångstr. 35. Hábito. 36. Detalhe do gametófito com esporófito. 37. Filídio. 38. Ápice do filídio. 39. Células da margem do filídio. 40. Células da base do filídio. Figuras 41-50. Callicostella pallida (Hornsch.) Ångstr. 41. Hábito. 42. Detalhe do gametófito com esporófito. 43. Filídio lateral. 44. Filídio dorsal. 45. Ápice do filídio lateral. 46. Detalhe da costa no ápice. 47. Células da margem do filídio. 48. Células medianas do filídio. 49. Células da base do filídio. 50. Detalhe da seta rugosa. Figuras 51-59. Callicostella rufescens (Mitt.) A. Jaeger. 51. Hábito. 52. Detalhe do gametófito com esporófito. 53. Filídio. 54-55. Ápice do filídio. 56. Células da margem do filídio. 57. Células medianas do filídio. 58. Células da base do filídio. 59. Detalhe da seta rugosa. 
caulídio e ramos com densos tufos de rizóides na superfície ventral e quatro fileiras de filídios na superfície dorsal (juláceos); filídios oblongos a oblongo-lanceolados, os dos ramos juláceos apresentando agrupamentos de propágulos castanhos e filamentosos; ápice agudo a curto ou longo-acuminado; margem serrulada a serreada do ápice até a base; sem costa; células lisas, as apicais linear-romboidais, as medianas e as basais mais longas. Esporófito não observado.

Material examinado: BRASIL. Rio de Janeiro: Casimiro de Abreu, Reserva Biológica de Poço das Antas, Rio São João, 19/VII/1994, Costa 2036 et al. (RB); Parati, trilha do Corisco até a Rasa, 13/XI/1990, Costa 1417 et al. (RB); Teresópolis, Serra dos Órgãos, 11/XII/1891, Ule s.n. (R 82043).

Material adicional: PANAMÁ: Bocas del Toro: Province Vicinity of Fortuna Dam, 2.8 road miles along pipeline road, leaving Chiriqui, Grande road at continental divide, 850-950 m, 25/VI/1986, Allen 5582 (RB).

De acordo com Florschütz-de Waard (1986), uma característica importante é a presença de propágulos filamentosos na base dos filídios dos ramos juláceos, que podem gerar esporófitos. No material examinado estes propágulos foram frequientes. $\mathrm{O}$ mesmo autor cita que o esporófito apresenta seta rugosa acima, cápsula ereta ou inclinada, caliptra mitrada, franjada na base, pilosa, com pêlos longos e septados.

Apresenta distribuição neotropical, com ampla ocorrência no Brasil, citada para os Estados do RR, PA, AM, AC, RO, PE, BA, RJ, SPe SC, entre 0-800 m. No Rio de Janeiro está amplamente distribuída, ocorrendo nos Municípios de Angra dos Reis, Casimiro de Abreu, Mangaratiba, Niterói, Parati, Rio de Janeiro, Silva Jardim e Teresópolis, como epífila, entre 0-800 m, predominando ao nível do mar. Status de conservação: Baixo Risco (LR).

\section{Cyclodictyon Mitt.}

Gametófito freqüentemente verde-pálido, complanado-foliado e irregularmente ramificado, caulídio em secção transversal com hialoderme, filídios bordeados por células alongadas, contrastando com as células laxas da lâmina.

Apresenta aproximadamente 70 espécies no Neotrópico, embora Gradstein et al. (2001) comentem que, após uma revisão este número seja reduzido para 30. É freqüentemente encontrado sobre solo ou líter e ocasionalmente sobre rochas, em locais úmidos, nas florestas de terra baixa a alto montana, entre 0-3.900 m (Gradstein et al. 2001). Para o Rio de Janeiro é confirmada a presença de quatro espécies, ocorrendo sobre troncos em decomposição, rochas e menos freqüentemente sobre raízes, geralmente associadas a cursos d'água, entre 0-2.400 m.

Chave para as espécies de Cyclodictyon

1. Filídios com borda apresentando 2-3 fileiras de células alongadas 4.1. C. albicans

1. Filídios com borda apresentando 1-2 fileiras de células alongadas

2. Costa não projetada no ápice 4.4. C. varians

2. Costa projetada no ápice

3. Filídios oblongos a ovados, margem inconspicuamente bordeada 4.3. C. olfersianum

3. Filídios ovados a oblongo-ovados, margem conspicuamente bordeada 4.2. C. limbatum

4.1 Cyclodictyon albicans (Hedw.) Kuntze, Revis. Gen. Pl. 2: 835. 1891. Tipo. Jamaica, Swartz s.n. (holótipo G).

Fig. 67-73

Cyclodictyon laxifolium Herzog, Hedwigia 67: 257. 1927. Tipo. Brasil, Serra dos Órgãos, Morro Assu, Luetzelburg 6632a (holótipo JE!); syn. nov.

Cyclodictyon glaucifolium (Müll. Hal.) Broth., Nat. Pflanzenfam. 1: 936. 1907. Tipo. Brasil, Serra de Itatiaia, Ule 1864 (isótipo R!); syn. nov.
Gametófito irregularmente ramificado a pinado; filídios torcidos quando secos e expandidos quando molhados, oblongos a oblongo-ovados; ápice cuspidado a abruptamente acuminado; margem bordeada com 2-3 fileiras de células alongadas, serrulada a serreada no ápice, inteira em direção à base; costa conspícua e dupla, alcançando 3/4-4/5 do compr. do filídio, com ápice projetado; células apicais e medianas isodiamétricas, tornando-se romboidais a longoretangulares na base. Esporófito com seta lisa, avermelhada e mais escura na base, cápsula horizontal 
a inclinada ou pendente. Caliptra não observada.

Material examinado: BRASIL. Rio de Janeiro: Itatiaia, Serra do Itatiaia, 4/VI/1902, Dusén 433 (R); Nova Friburgo, Pico da Caledônia, 2.018 m, 4/V/1988, Costa 661 et al. (RB).

Material adicional: BRASIL. Rio Grande do Sul: Dois Irmãos, Morro Dois Irmãos, XI/1971, 100 m, Sehnem 11902 (RB); Montenegro, Linha São Pedro, 500 m, 11/VI/1946, Sehnem 399 (RB).

Buck (1998) descreveu os filídios laterais como assimétricos e os ventrais simétricos, entretanto, essa diferenciação não foi observada no material examinado, onde os filídios laterais e ventrais se apresentaram sempre simétricos.

Apresenta distribuição neotropical, ocorrendo no Brasil nos Estados de MT, MS, MG, RJ, PR e RS, entre 800-1.600 m. No Rio de Janeiro ocorre nos Municípios de Itatiaia e Nova Friburgo, sendo aqui citada para Teresópolis, sobre solo e rochas úmidas, entre 800-2.400 m. Status de conservação: Baixo Risco (LR).

4.2 Cyclodictyon limbatum (Hampe) O. Kuntze, Revis. Gen. Pl. 2: 835. 1891. Tipo. Brasil, Rio de Janeiro, Glaziou 7221 (holótipo MANCH).

Fig. 74-79

Gametófito irregularmente ramificado; filídios ovados a oblongo-ovados; ápice acuminado; margem bordeada por 1-2 fileiras de células alongadas, fracamente serreado a serrulado acima, inteira em direção à base; costa conspícua e dupla, alcançando 2/3 do compr. do filídio (onde se inicia o estreitamento foliar), com ápice projetado; células apicais e medianas arredondado-romboidais, as basais longo-romboidais a retangulares. Esporófito com seta lisa, cápsula horizontal a pendente. Caliptra não observada.

Material examinado: BRASIL. Rio de Janeiro: Petrópolis, 16/II/1924, Bandeira s.n. (RB 174403).

Material adicional: BRASIL. Rio Grande do Sul: Bom Jesus, Arroio das Capoeiras, 950 m, 15/I/1942, Sehnem 292 (PACA); Piratiny, 8/XII/1893, Lindman s.n. (R 82020); São Francisco de Paula, 900 m, 19/XII/1949, Sehnem 4605 (PACA); São Leopoldo, Horto Florestal, 50 m, 28/X/1941, Sehnem 203 (PACA). Santa Catarina: Lages, 960 m, 10/I/1951, Sehnem 5433a (PACA).

Ocorre na América do Sul, Galápagos e pequenas Antilhas. No Brasil, na região sul e Estados do RJ e SP, entre 0-1.200 m. No Rio de Janeiro ocorre no Município de Itatiaia, sendo aqui citada para Petrópolis, sobre solo úmido, rocha, troncos caídos, geralmente associados a cursos d'água, acima de 800 m. Status de conservação: Baixo Risco (LR).

4.3 Cyclodictyon olfersianum (Hornsch.) O. Kuntze, Revis. Gen. Pl. 2: 835. 1891. Tipo. Brasil, Rio de Janeiro, Tijuca, Olfers s.n.; ibid. Sellow s.n. (síntipos BM).

Fig. 80-84

Gametófito irregularmente ramificado; filídios oblongos a ovados; ápice acuminado; margem com borda inconspícua, composta por 1-2 fileiras de células alongadas, sinuada a inteira acima e levemente serrulada em direção à base; costa dupla, alcançando 2/3 do compr. do filídio, com ápice projetado; células apicais e medianas longo-romboidais, tornando-se retangulares em direção a base. Esporófito com seta avermelhada, lisa, cápsula horizontal ou pendente. Caliptra não observada.

Material examinado: BRASIL. Rio de Janeiro: Nova Friburgo, Estrada de Vargem Alta para Friburgo, 11/XII/1987, Costa 506 et al. (RB).

Material adicional: BRASIL. Minas Gerais: Fazenda Bom Destino, 22/II/1924, GUA 11622 M. Bandeira (HRJ).

Sehnem (1979) descreveu a caliptra como subulada.

Citado para Antilhas e Brasil, nesse último ocorrendo na região sul e Estados de MG, RJ e SP, entre 0-1.100 m. No Rio de Janeiro ocorre nos Municípios de Nova Friburgo, Petrópolis e Rio de Janeiro, sobre troncos de árvores, rochas próximo a córregos, entre 0-1.100 m. Status de conservação: Baixo Risco (LR).

4.4 Cyclodictyon varians (Sull.) O. Kuntze, Revis. Gen. Pl. 2: 835. 1891. Tipo. Cuba, Wright s.n. (holótipo $\mathrm{FH})$.

Fig. 85-89

Gametófito irregularmente ramificado a pinado; filídios pouco ou não contorcidos quando secos, oblongos a ovados; ápice cuspidado a gradualmente acuminado; margem bordeada com 1-2 fileiras de células alongadas, serrulada acima e sinuada a inteira em direção à base; costa dupla, alcançando ca. 2/3 do compr. do filídio, com ápice não projetado; células laxas, as apicais e medianas romboidais a isodiamétricas (1-2:1), as basais longo-romboidais a retangulares. Esporófito com seta lisa, amarelada acima e avermelhada na base, curvada no ápice, com cápsula inclinada a horizontal. Caliptra não observada.

Material examinado: BRASIL. Rio de Janeiro: Mangaratiba, Km 54 da Rodovia Rio-Santos, Reserva Ecológica Rio das Pedras, 25/III/1993, Oliveira-e- 

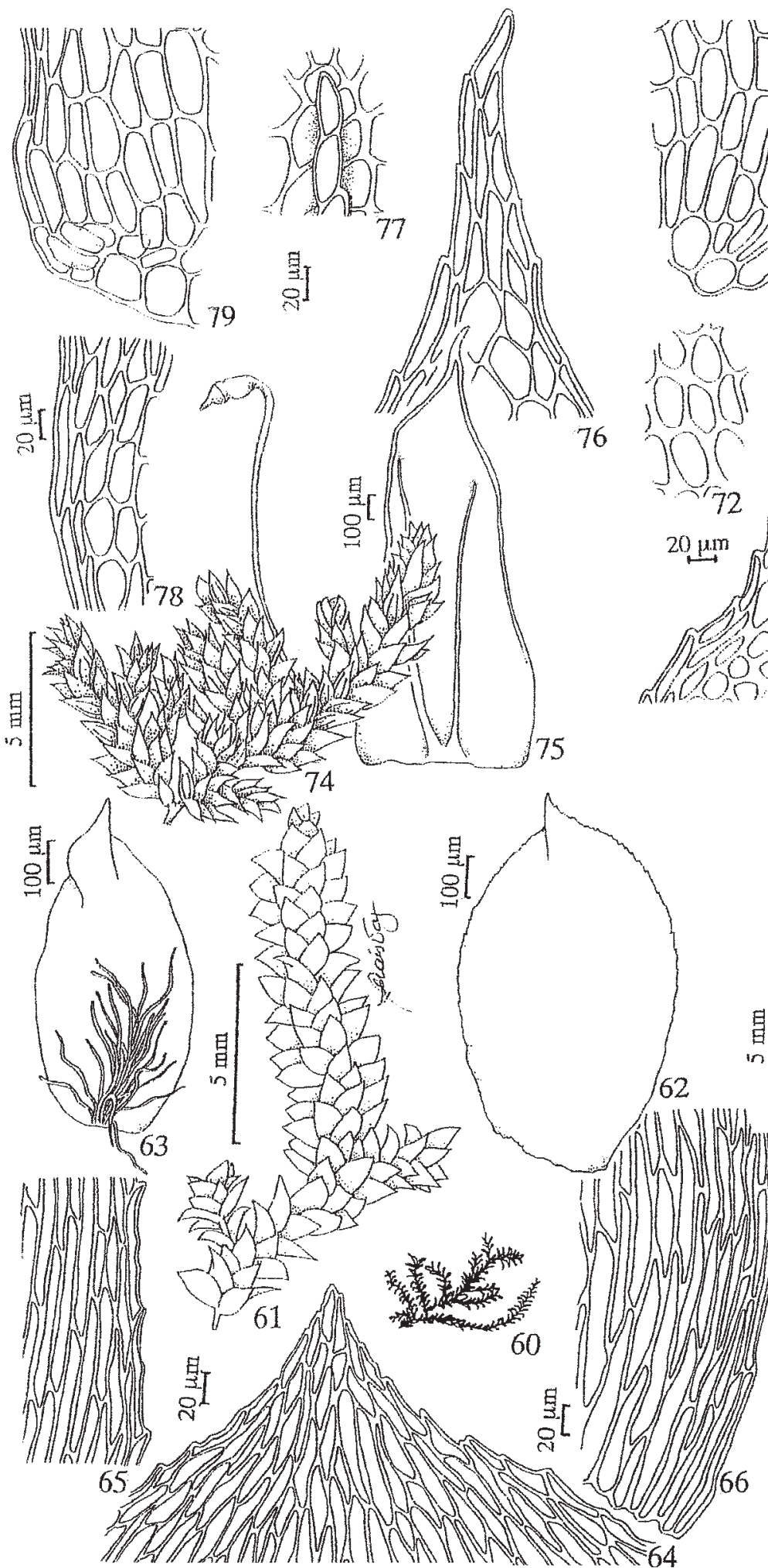
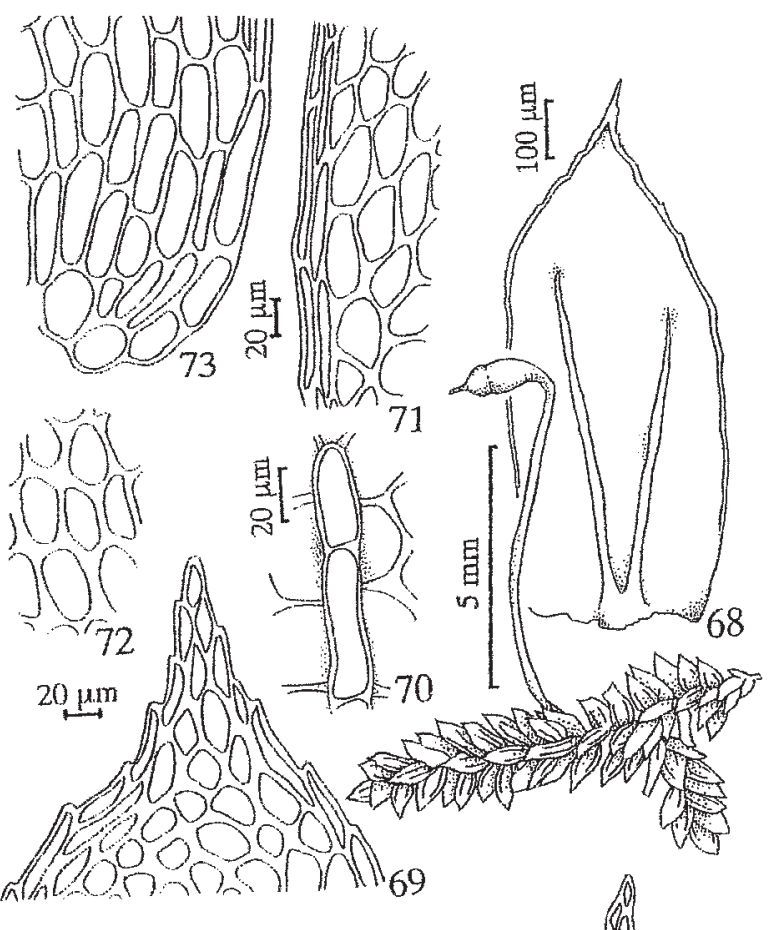

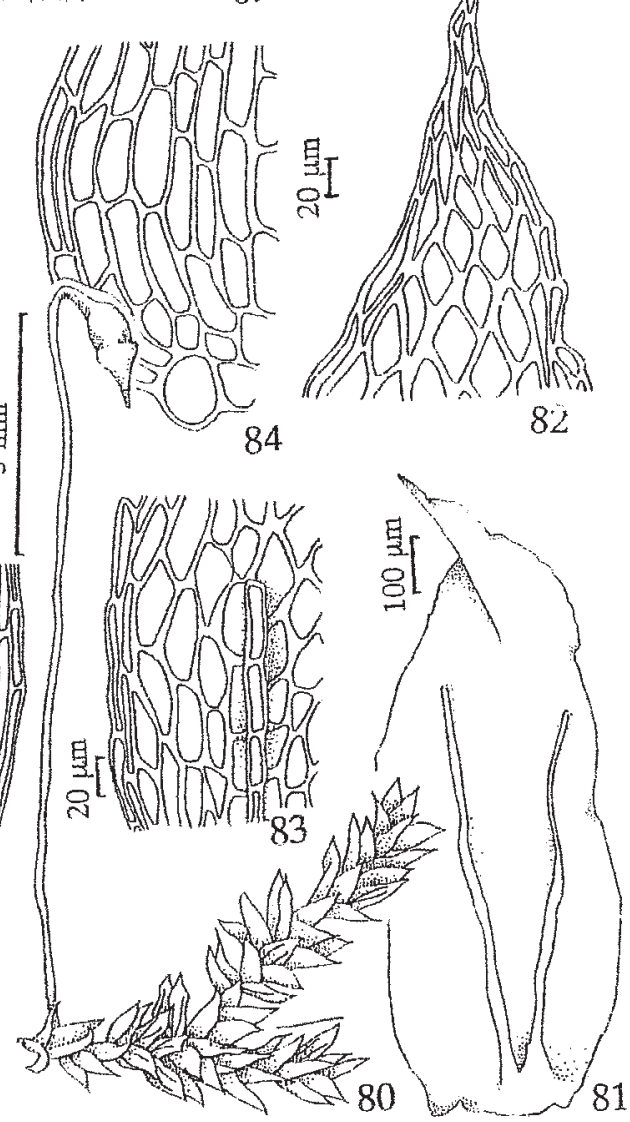

Figuras 60-66. Crossomitrium patrisiae (Brid.) Müll. Hal. 60. Hábito. 61. Detalhe do gametófito. 62. Filídio. 63. Filídio com propágulos na base. 64. Ápice do filídio. 65. Células da margem do filídio. 66. Células da base do filídio. Figuras 67-73. Cyclodictyon albicans (Hedw.) Kuntze. 67. Detalhe do gametófito com esporófito. 68. Filídio. 69. Ápice do filídio. 70. Detalhe da costa no ápice. 71. Células da margem do filídio. 72. Células medianas do filídio. 73. Células da base do filídio. Figuras 74-79. Cyclodictyon limbatum (Hampe) O. Kuntze. 74. Detalhe do gametófito com esporófito. 75. Filídio. 76. Ápice do filídio. 77. Detalhe da costa no ápice. 78. Células da margem do filídio. 79. Células da base do filídio. Figuras 80-84. Cyclodictyon olfersianum (Hornsch.) O. Kuntze. 80. Detalhe do gametófito com esporófito. 81. Filídio. 82. Ápice do filídio. 83. Detalhe da costa no ápice e células da margem do filídio. 84. Células da base do filídio. 
Silva 234 (HRJ); ibid. 5/VIII/1993, Oliveira-e-Silva 595-A (HRJ); ibid. 1/XII/1993, Oliveira-e-Silva 1119 (HRJ).

Este táxon pode ser confundido com C. albicans, diferenciando-se pela margem bordeada por uma fileira de células mais alongadas, serrulada e costa no ápice não projetada.

Segundo Buck (1998), a caliptra é mitrada e lisa.

Apresenta distribuição na América tropical alcançando o sul dos Estados Unidos. No Brasil, ocorre nos Estados do AM, MS, RJ e SP, entre 0-340 m. No Rio de Janeiro, ocorre nos Municípios de Angra dos Reis, Casimiro de Abreu, Mangaratiba e Niterói, entre 0-500 m, sobre troncos caídos, rochas e raízes, associadas a cursos d'água. Status de conservação: Baixo Risco (LR).

Espécies excluídas do estudo:

Cyclodictyon cuspidatum O. Kuntze - Não foi possível examinar nenhum material desta espécie oriundo do Estado do Rio de Janeiro o que corrobora a caracterização de Costa et al. (2005), na categoria de Dados Deficientes (DD). Citada sem localidade para o Estado, por Hampe (1879).

Cyclodictyon leucomitrium (Müll. Hal.) Broth. - Embora tenha sido citada sem localidade para o Estado, por Luetzelburg (1923), até o momento não foi possível examinar material dessa espécie oriundo do Estado do Rio de Janeiro.

Cyclodictyon rivale (Müll. Hal.) Broth. Examinando o material do herbário do Museu Nacional (R), constatou-se a forte semelhança deste com Cyclodictyon limbatum. Como não foi possível examinar a obra original de Hookeria rivalis Müll. Hal. e localizar onde está depositado o material tipo, o sinônimo não pode ser realizado.

\section{Hookeriopsis (Besch.) A. Jaeger}

Gametófito de tamanho reduzido, irregularmente ramificado, caulídio em secção transversal sem hialoderme, filídios lanceolados, margem não diferenciada, serrulada, costa curta, alcançando $\pm 1 / 2$ do compr. do filídio, areolação homogênea.

Buck (1987), estudando a família, rearranjou parte das espécies de Hookeriopsis em três gêneros: Brymela, Thamniopsis e Trachyxiphium.

Hookeriopsis se diferencia de Brymela por apresentar gametófitos menos robustos, costa mais curta (terminando \pm na $1 / 2$ do compr. do filídio) e filídios serrulados; de Thamniopsis pelo caulídio sem hialoderme, margem do filídio sem dentes inflados, costa não projetada no ápice e areolação homogênea; e, finalmente, de Trachyxiphium por não apresentar na margem dentes inflados, costa não projetada.

Gradstein et al. (2001) citam duas espécies de Hookeriopsis para o Neotrópico, H. leiophylla (Besch.) A. Jaeger e H. luteorufescens (Besch.) A. Jaeger, considerando ainda 30 espécies como indefinidas. Para Buck (1987), Hookeriopsis sensu stricto apresenta apenas estas duas espécies. Apesar da única espécie do gênero presente no Rio de Janeiro, H. rubens (Müll. Hal.) Broth., não ser citada por Buck (1987), preferimos mantê-la neste estudo, uma vez que apresenta características pertinentes ao gênero.

No Neotrópico, geralmente ocorre sobre raízes, base do tronco de árvores, troncos em decomposição e rochas, principalmente nas florestas nebulosas, entre 940-1.095 m (Gradstein et al. 2001). No Rio de Janeiro, foi observado ocorrendo sobre rochas, geralmente associadas a curso d'água, entre 800-1.400 m.

5.1 Hookeriopsis rubens (Müll. Hal.) Broth., Nat. Pflanzenfam. 1: 941. 1907. Tipo. Brasil, Santa Catarina, Ilha de São Francisco, VII-1884, Ule 35 (holótipo HBG).

Fig. 90-97

Gametófito verde a castanho-avermelhado, irregularmente ramificado a pinado; filídios lanceolados; ápice agudo a longo-acuminado; margem serrulada acima, sinuada a inteira em direção à base; costa inconspícua e dupla, rubescente, alcançando metade do compr. do filídio; células estreitas e lineares, apresentando proporção entre comprimento e largura de 15-20:1, levemente mais alongadas em direção à base. Esporófito não observado.

Material examinado: BRASIL. Rio de Janeiro: Nova Friburgo, estrada de Olaria para São Lourenço, 1.440 m, 29/III/1989, Costa et al. 857 (RB).

Segundo Sehnem (1979), o esporófito apresenta seta retorcida e delicada e cápsula horizontal.

Hookeriopsis rubens é endêmica do Brasil, ocorrendo nos Estados do RJ, SP, PR e SC, entre 0-1.200 m. No Rio de Janeiro ocorre nos Municípios de Nova Friburgo e Teresópolis, sobre tronco caído e pedra de rio, entre 800-1.400 m. Status de conservação: Baixo Risco (LR).

Espécies excluídas do estudo:

Hookeriopsis brachypelma (Müll. Hal.) Broth. - Possivelmente trata-se de uma espécie de Thamniopsis, visto que Müller (1900) descreveu as 
células maiores na base, o que pode caracterizar uma areolação heterogênea típica desse gênero. Entretanto, a nova combinação não pôde ser realizada, uma vez que o tipo não pôde ser localizado. Costa et al. (2005), incluem essa espécie na categoria de Dados Deficientes (DD), visto que o conhecimento taxonômico está restrito a obra original.

Hookeriopsis corcovadensis (Reichardt) A. Jaeger - Não foi possível examinar nenhum material dessa espécie para o Estado, que é considerada por Crosby et al. (1999) como insuficientemente conhecida.

Hookeriopsis hydrophila (Müll. Hal.) Broth. - O material do herbário PACA examinado foi considerado muito semelhante a Thamniopsis langsdorffii e comparando as descrições da obra original (Müller 1900) com a de Sehnem (1979), constatou-se que podem se tratar da mesma planta. Entretanto, não foi possível examinar o material tipo.

Hookeriopsis puiggarii (Geh. \& Hampe) Broth. - O material do herbário PACA examinado foi considerado similar a Thamniopsis langsdorffii. As descrições de Hampe (1879) e Sehnem (1979) foram comparadas, indicando que essas podem ser sinônimos. Entretanto não foi possível examinar o material tipo. Categorizada por Costa et al. (2005), como uma espécie vulnerável (VU) no Estado do Rio de Janeiro por ser conhecida somente para o Município de Nova Friburgo (Sehnem 1979).

\section{Hypnella (Müll. Hal.) A. Jaeger}

Gametófito irregularmente a livremente ramificado, caulídio em secção transversal sem hialoderme, filídios com margem não diferenciada, exceto em alguns casos em que apresenta fileiras de células lisas, células da lâmina lineares, com 2-5(-7) papilas unisseriadas sobre o lúmen, o que facilmente difere o gênero dos demais estudados. Segundo Crosby et al. (1985), o esporófito apresenta seta alongada, papilosa a escabrosa no ápice, dentes do exóstoma estriados transversalmente e caliptra mitrada.

Apresenta seis espécies no Neotrópico, ocorrendo sobre solo, rocha, líter, troncos em decomposição e, ocasionalmente, em troncos de árvores, em florestas de terra baixa a alto montana, entre 100-3.000 m (Gradstein et al. 2001). Para o Estado do Rio de Janeiro foi confirmada a presença apenas de H. pilifera (Hook. \& Wils.) A. Jaeger, ocorrendo entre 800-1.600 m.
6.1 Hypnella pilifera (Hook. \& Wils.) A. Jaeger, Ber. Thätigk. St. Gallischen Naturwiss. Ges. 1875-76: 366. 1877. Tipo. Brasil, Rio de Janeiro, Serra dos Órgãos, III-1837, Gardner 89 (lectótipo BM, designado por Crosby et al. (1985); isolectótipos BM, FH, NY).

Fig. 98-104

Gametófito irregularmente ramificado a bipinado; filídios planos, oblongos a ovados; ápice aristado; margem serreada a serrulada acima e serrulada em direção à base; costa dupla, quase alcançando 1/2-3/5 do compr. do filídio; células longo-romboidais com 2-5 pequenas papilas unisseriadas sobre o lúmen, as apicais menos papilosas a lisas e as basais retangulares e com menos papilas. Esporófito com seta toda lisa, cápsula inclinada a pendente. Caliptra não observada.

Material examinado: BRASIL. Rio de Janeiro: Teresópolis, Serra dos Órgãos, VIII/1958, Schnell 8307 (RB).

Material adicional: BRASIL. Rio Grande do Sul: Montenegro, Linha de Júlio de Castilhos, $450 \mathrm{~m}$, 8/XI/1949, Sehnem 4035 (RB).

Segundo Welch (1976), o esporófito apresenta seta minusculamente papilosa, sendo lisa somente na base.

Apresenta distribuição neotropical, no Brasil ocorrendo no Estado da PB e nas regiões sudeste e sul, entre 0-2.000 m. No Rio de Janeiro, ocorre nos Municípios de Nova Friburgo e Teresópolis, sobre solo, troncos caídos e rochas, geralmente associada a cursos d'água, entre 800-1.600 m. Status de conservação: Baixo Risco (LR).

Espécies excluídas do estudo:

Hypnella leptorrhyncha (Hook. \& Grev.) A. Jaeger - Segundo Crosby et al. (1985) e Allen (1986) esta espécie não ocorre no Brasil.

Hypnella pallescens (Hook) A. Jaeger - Não foi possível examinar nenhum material dessa espécie oriundo do Estado do Rio de Janeiro, embora tenha sido citada para o Município do Rio de Janeiro por Crosby et al.(1985).

Hypnella punctata Broth. - Não foi possível examinar nenhum material oriundo do Estado do Rio de Janeiro dessa espécie, que é incluída por Costa et al. (2005) na categoria de Dados Deficientes (DD) por ser endêmica do Estado e conhecida somente pelo material tipo coletado por Glaziou há mais de 100 anos.

\section{Trachyxiphium W.R. Buck}

Gametófito irregularmente ramificado, caulídio, em secção transversal, sem hialoderme desenvolvida, 

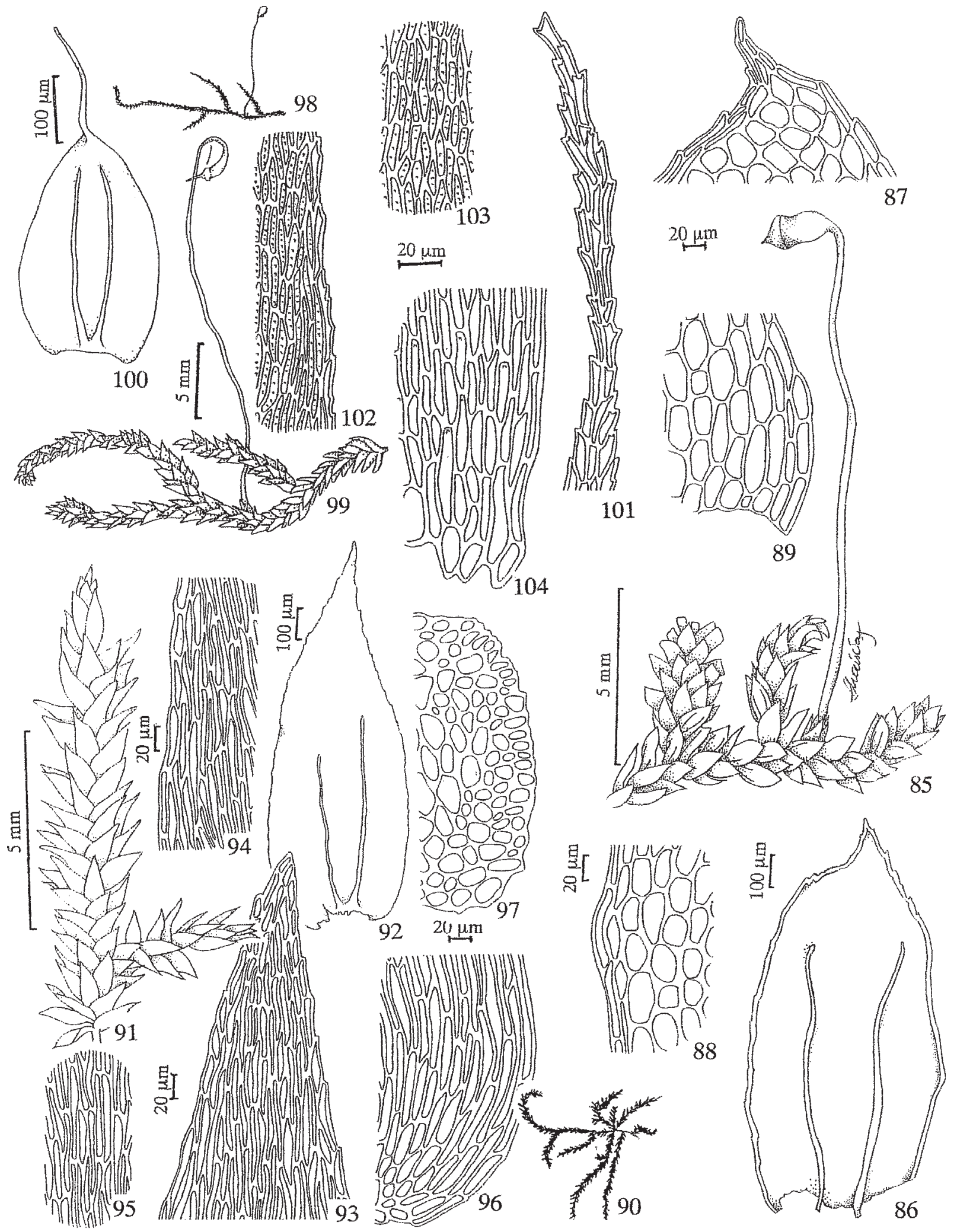

101
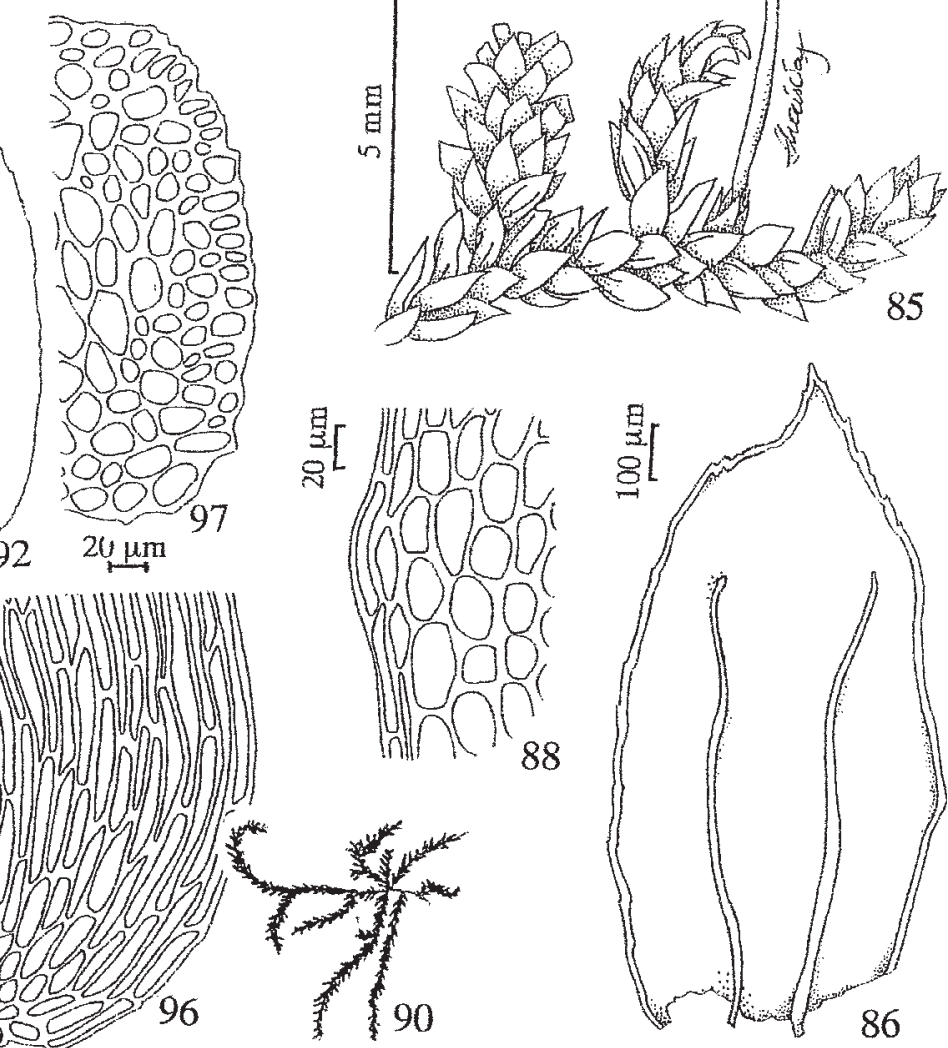

Figuras 85-89. Cyclodictyon varians (Sull.) O. Kuntze. 85. Detalhe do gametófito com esporófito. 86. Filídio. 87. Ápice do filídio. 88. Células da margem do filídio. 89. Células da base do filídio. Figuras 90-97. Hookeriopsis rubens (Müll. Hal.) Broth. 90. Hábito. 91. Detalhe do gametófito. 92. Filídio. 93. Ápice do filídio. 94. Células da margem do filídio. 95. Células medianas do filídio. 96. Células da base do filídio. 97. Secção transversal do caulídio. Figuras 98-104. Hypnella pilifera (Hook. \& Wils.) A. Jaeger. 98. Hábito. 99. Detalhe do gametófito com esporófito. 100. Filídio. 101. Ápice do filídio. 102. Células da margem do filídio. 103. Células medianas do filídio. 104. Células da base do filídio. 
filídios com ápice longo-acuminado, margem não diferenciada, com dentes bífidos e inflados, costa dupla, alongada, células com papila no ângulo apical. Segundo Gradstein et al. (2001), o esporófito apresenta seta alongada, lisa ou, ocasionalmente, rugosa.

Gênero neotropical, com 10-15 espécies, ocorrendo sobre húmus, troncos em decomposição, raízes expostas, troncos e ramos de arbustos e árvores, eventualmente sobre solo e rochas em locais muito úmidos, nas florestas montanas primárias e secundárias, raramente nas florestas de terra baixa, entre 0-3.755 m (Gradstein et al. 2001). Segundo Buck (1998), o gênero alcança máxima diversidade nos Andes e leste do Brasil. No Estado do Rio de Janeiro, está representado por três espécies, ocorrendo sobre rochas e troncos em decomposição, freqüentemente associados a cursos d'água, entre 0-2.200 m.

\section{Chave para as espécies de Trachyxiphium}

1. Costa alcançando até $4 / 5$ do compr. do filídio, com ápice projetado, podendo ser cristado

2. Filídios ligeiramente diferenciados, os laterais assimétricos e dorsais/ ventrais simétricos, lanceolados a ovado-lanceolados; ápice da costa cristado 7.2. T. guadalupense

2. Filídios não diferenciados, ovados; ápice da costa nunca cristado 7.3. T. variabile

1. Costa alcançando mais de $4 / 5$ do compr. do filídio, com ápice não projetado, nunca cristado 7.1. T. aduncum

7.1 Trachyxiphium aduncum (Mitt.) W.R. Buck, Brittonia 39: 220. 1987. Tipo. Peru, Tarapoto, rio Cumbasa, Spruce 650 (holótipo NY).

Fig. 105-112

Gametófito verde-amarelado a avermelhado, irregularmente ramificado; filídios lanceolados a ovadolanceolados; ápice longo-acuminado; margem serreada no ápice, com dentes inflados, alguns bífidos; costa dupla, divergente na base e paralela no ápice, alcançando mais de $4 / 5$ do compr. do filídio, com ápice denteado e não projetado; células com papila no ângulo apical, no ápice longo-romboidais, as medianas lineares e as basais retangulares. Esporófito não observado.

Material examinado: BRASIL. Rio de Janeiro: Itatiaia, Reserva Florestal de Itatiaia, 4/IX/1924, Occhioni s.n. (RB 174398); Nova Friburgo, Macaé de Cima, Rio das Flores, Silva s.n. (RB 301380).

É muito semelhante a $T$. variabile, diferenciando-se por apresentar costa denteada e não projetada no ápice. Sehnem (1979) descreveu o esporófito com seta lisa, longa, avermelhada e cápsula horizontal.

Ocorre na Bolívia e Brasil, e, nesse último, nos Estados do RJ, SP e RS, entre 900-2.200 m. No Rio de Janeiro ocorre nos Municípios de Itatiaia, Nova Friburgo, Petrópolis e Teresópolis, sobre rocha de rio e tronco caído, entre 900-2.200 m. Status de conservação: Baixo Risco (LR).

7.2 Trachyxiphium guadalupense (Brid.) W.R. Buck, Brittonia 39: 220. 1987. Tipo. Guadalupe, ex herb. Candolle (holótipo B!).

Fig. 113-121

Trachyxiphium hypnaceum (Müll. Hal.) W.R. Buck, Brittonia 39: 220. 1987. Tipo. Brasil, Santa Catarina, Pabst s.n. (lectótipo BM!, designado por Buck 1987); syn. nov.

Gametófito verde-claro, irregularmente ramificado a pinado; filídios ligeiramente diferenciados, os laterais assimétricos e os ventrais/dorsais simétricos, lanceolados a ovado-lanceolados; ápice longoacuminado; margem serreada na metade superior do filídio e inteira na metade inferior, no ápice com todas as células formando dentes inflados e bífidos; costa dupla, alcançando 3/4 do compr. do filídio, com ápice cristado e denteado na metade superior do filídio; células com papila no ângulo apical, na região apical e mediana longo-romboidais e na basal maiores e com menos papilas. Esporófito com seta lisa e avermelhada, cápsula inclinada a pendente. Caliptra não observada.

Material examinado: BRASIL. Rio de Janeiro: Itatiaia, Caminho para o Véu da Noiva, $1.100 \mathrm{~m}$, 15/II/1994, Andrade s.n. (RB 382550); Nova Friburgo, estrada de Olaria para São Lourenço, $1.400 \mathrm{~m}$, 29/III/1989, Costa et al. 859 (RB); Teresópolis, Serra dos Órgãos, 1.120 m, 31/VII/1986, Schäfer-Verwimp \& Verwimp 7393 (como Trachyxiphium hypnaceum, $\mathrm{MO}$ ).

Material adicional: BRASIL. Rio Grande do Sul: Dois Irmãos, Morro Reuter, 700 m, 22/II/1965, Sehnem 8379 (como Hookeriopsis hypnaceae, PACA); Montenegro, Linha Júlio de Castilhos, 450 m, 8/XI/1949, Sehnem 4040, 4930 (como H. hypnaceae, PACA); São Leopoldo, Fazenda São Borja, 50 m, 8/X/1941, Sehnem 15597 (como H. hypnaceae, PACA).

Segundo Buck (1998), a caliptra é mitrada, glabra ou pouco pilosa. 
Apresenta distribuição neotropical e, no Brasil, é citada para as regiões sudeste e sul, entre $800-1.400 \mathrm{~m}$. No Rio de Janeiro, ocorre nos Municípios de Nova Friburgo, Rio de Janeiro e Teresópolis (como T. hypnaceum), sendo aqui citada para Itatiaia. Encontrada geralmente sobre rocha e solo, associada a cursos d'água, entre 0-1.400 m. Status de conservação: Baixo Risco (LR).

7.3 Trachyxiphium variabile (Mitt.) W.R. Buck, Brittonia 39: 221. 1987. Tipo. Brasil, Rio de Janeiro, Gardner s.n. (lectótipo NY, designado por Buck 1987).

Fig. 122-128

Gametófito verde-claro, irregularmente ramificado; filídios ovados, os laterais e os ventrais/dorsais não diferenciados; ápice longo-acuminado; margem serreada a serrulada acima, com dentes inflados, alguns bífidos, e inteira em direção à base; costa dupla, alcançando 3/4 do compr. do filídio, com ápice fracamente denteado e não cristado; células com papila no ângulo apical, na região apical e mediana longoromboidais a lineares, na basal retangulares. Esporófito com seta lisa, cápsula inclinada. Caliptra não observada.

Material examinado: BRASIL. Rio de Janeiro: Nova Friburgo, Theodoro de Oliveira, 27/III/1989, 1.100 m, Costa et al. 739 (RB).

Apresenta distribuição neotropical, citada no Brasil para os Estados do RJ, SP e RS, até 1.200 m. No Rio de Janeiro ocorre nos Municípios do Rio de Janeiro, Teresópolis e Nova Friburgo. Geralmente, sobre rocha e troncos caídos, associados a cursos d'água, entre 0-1.100 m. Status de conservação: Baixo Risco (LR).

\section{Discussão}

O estudo das 18 espécies desses sete gêneros de Pilotrichaceae permitiu realizar algumas análises pertinentes ao estado do conhecimento da família no Estado do Rio de Janeiro e no Brasil, principalmente no que se refere à variação altitudinal, distribuição geográfica e status de conservação dos táxons.

Em relação à variação altitudinal, os dados demonstram que a maior riqueza ocorreu na faixa montana, entre 500-1.500 m, que apresentou 12 espécies (34\% do total de espécies de Pilotrichaceae para o Estado), das quais cinco são restritas a esta faixa. Entre 0-200 m, na faixa de terra baixa, ocorreram 11 espécies, na sub-montana oito, e na alto montana duas. Três espécies estão restritas à terra baixa, nenhuma à sub-montana e alto montana.
A maior riqueza observada na faixa montana já era esperada, uma vez que nos trópicos, estas florestas são mais ricas em número de espécies do que a faixa de terra baixa e sub-montana (Gradstein et al. 2001). Além disso, existem diversas Unidades de Conservação situadas nesta faixa altitudinal no Estado. O grande número de espécies de Pilotrichaceae observado nas florestas de terra baixa do Estado corrobora os dados de Gradstein \& Costa (2003), que sugerem que estas florestas, nas regiões tropicais, podem ser menos pobres em espécies do que têm sido sugerido.

Somente dois padrões de distribuição, neotropical e endêmico do Brasil, foram observados nos táxons estudados. Das 18 espécies, 14 (78\%) são neotropicais e 4 (22\%) endêmicas do Brasil.

Das espécies estudadas, três (16\%) apresentam ampla distribuição, ocorrendo em mais de três regiões do Brasil, sete (39\%) são exclusivas das regiões sul e sudeste, uma (6\%) da região sudeste e sete (39\%) ocorrem de maneira descontínua entre o sudeste e outras regiões. Esses dados indicam a importância das espécies dos gêneros de Pilotrichaceae na região sudeste do Brasil, que pode ser considerada um dos centros de diversidade da família no país. Além disso, a distribuição descontínua de $44 \%$ das espécies pode indicar tanto a carência de coletas em áreas intermediárias, bem como a baixa representatividade das espécies dessa família nestas áreas, uma vez que esta família está preferencialmente distribuída em regiões úmidas.

Dos 92 municípios do Estado do Rio de Janeiro, somente 12 apresentam registros para as espécies de Pilotrichaceae tratadas neste estudo. Este fato demonstra que o Estado ainda é carente de levantamentos florísticos de briófitas, onde, das 38 Unidades de Conservação, nove têm a sua brioflora totalmente desconhecida.

Com base nos dados disponíveis até o momento, é possível afirmar que os municípios que apresentaram maior riqueza foram Nova Friburgo e Rio de Janeiro, devido ao fato de possuírem levantamentos da sua brioflora. Isso demonstra a importância deste tipo de estudo para o conhecimento da flora do Estado e do primeiro município estar situado na faixa com maior riqueza de espécies desta família e apresentar Unidade de Conservação.

Novas ocorrências de espécies da família são citadas neste estudo para quatro municípios do Estado do Rio de Janeiro, enfatizando a importância de se examinar material de diversos herbários que contenham coleções de briófitas. 

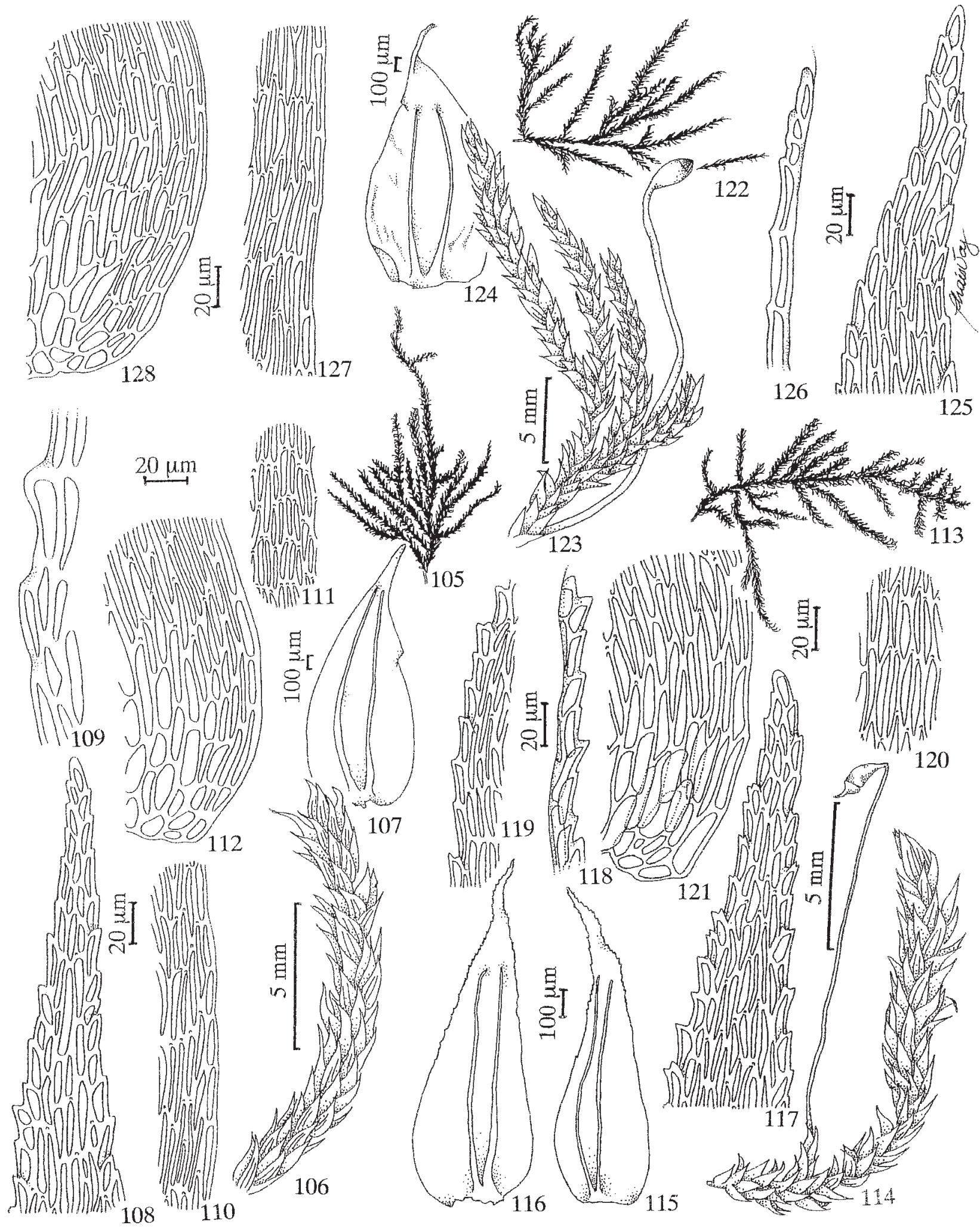

125

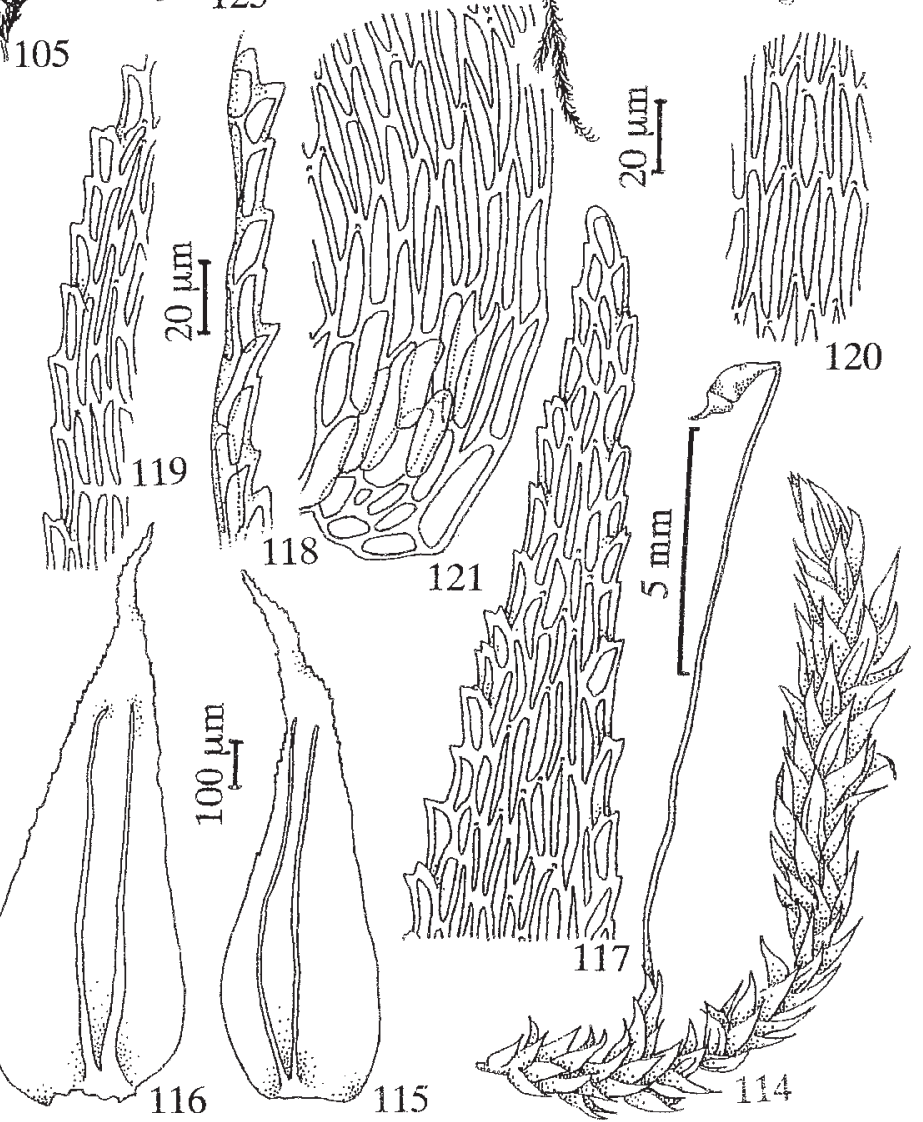

Figuras 105-112. Trachyxiphium aduncum (Mitt.) W.R. Buck. 105. Hábito. 106. Detalhe do gametófito. 107. Filídio. 108. Ápice do filídio. 109. Detalhe da costa no ápice. 110. Células da margem do filídio. 111. Células medianas do filídio. 112. Células da base do filídio. Figuras 113-121. Trachyxiphium guadalupense (Brid.) W.R. Buck. 113. Hábito. 114. Detalhe do gametófito com esporófito. 115. Filídio lateral. 116. Filídio dorsal. 117. Ápice do filídio. 118. Detalhe da costa no ápice. 119. Células da margem do filídio. 120. Células medianas do filídio. 121. Células da base do filídio. Figuras 122-128. Trachyxiphium variabile (Mitt.) W.R. Buck. 122. Hábito. 123. Detalhe do gametófito com esporófito. 124. Filídio. 125. Ápice do filídio. 126. Detalhe da costa no ápice. 127. Células da margem do filídio. 128. Células da base do filídio. 
Os dados sobre o status de conservação dos táxons no Rio de Janeiro demonstram que a família se apresenta em bom estado de conservação, visto que 16 espécies $(88 \%)$ foram caracterizadas como de baixo risco. Isto se deve, possivelmente, a ampla distribuição das espécies na Mata Atlântica do Estado e a sua ocorrência em áreas protegidas por Unidades de Conservação.

\section{Agradecimentos}

As autoras agradecem aos curadores dos herbários B, BM, HRJ, JE, MO, PACA, R e RB, pelo empréstimo dos materiais; ao Prof. Paulo Eduardo Aguiar Saraiva Câmara e ao Dr. Bruce Allen, ambos do Missouri Botanical Garden, ao primeiro pelo envio de bibliografia e ao segundo por disponibilizar a ilustração de uma espécie. A primeira autora agradece a CAPES, pela bolsa concedida.

\section{Referências bibliográficas}

Allen, B. 1986. The taxonomic status of Hypnella punctata. The Bryologist 89: 224-226.

Allen, B. 1990. A revision of the Genus Crossomitrium (Musci: Hookeriaceae). Tropical Bryology 2: 3-34.

Brotherus, V.F. 1894. Musci Schenckiani. Ein Beitrag zur Kenntniss der Moosflora Brasiliens. Hedwigia 33: 127-136.

Brotherus, V.F. 1895a. Beiträge zur Kenntniss der brasilianischen Mossflora. Hedwigia 34: 117-131.

Brotherus, V.F. 1895b. Nouvelles contributions à la flore bryologique du Brésil. Bihang til Kongliga svenska vetenskaps-akademiens handlingar 21(3): 3-76.

Buck, W.R. 1987. Taxonomic and nomenclatural rearrangement in the Hookeriales with notes on West Indian taxa. Brittonia 39: 210-224.

Buck, W.R. 1998. Pleurocarpous Mosses of The West Indies. Memoirs of The New York Botanical Garden 82: 1-400.

Buck, W.R. \& Goffinet, B. 2000. Morphology and classification of mosses. Pp. 71-123. In: A.J. Shaw \& B. Goffinet (eds.). Bryophyte Biology. England, Cambridge University Press.

Costa, D.P. 1995. Musgos do Município de Nova Friburgo, Rio de Janeiro, Brasil. Arquivos do Jardim Botânico do Rio de Janeiro 33: 99-118.

Costa, D.P.; Imbassahy, C.A.A. \& Silva, V.P.A.V. 2005. Diversidade e importância das espécies de briófitas na conservação dos ecossistemas do Estado do Rio de Janeiro. Rodriguésia 56(87): 13-49.

Crosby, M.R.; Magill, R.E. \& Allen, B. 1985. A review of the moss genus Hypnella. The Bryologist 88: 121-129.

Crosby, M.R.; Magill, R.E.; Allen, B. \& He, S. 1999. A Checklist of the Mosses. St. Louis, USA, Missouri Botanical Garden.
Dusén, P. 1903. Sur la flore de la Serra do Itatiaya au Brésil. Arquivos do Museu Nacional do Rio de Janeiro 13: 1-119.

Florschütz-de-Waard, J. 1986. Musci. Part II. Pp. 273-361. In: A.L. Stoffers \& J.C. Lindeman (eds.). Flora of Suriname. v. 6. Brill, Leiden.

Gradstein, S.R. \& Costa, D.P. 2003. The Hepaticae and Anthocerotae of Brazil. Memoirs of The New York Botanical Garden 88: 1-318.

Gradstein, S.R.; Churchill, S.P. \& Salazar-Allen, N. 2001. Guide to the Bryophytes of Tropical America. Memoirs of the New York Botanical Garden 86: 1-577.

Hampe, E. 1872. Musci frondosi. Pp. 36-59. In: Warming (ed.). Symbolae ad floram Brasiliae centrales cognoscendam. Videnskabelige Meddelelser fra dansk naturhistoriske Forening i Kjöbenhavn, ser. 3, 10.

Hampe, E. 1874a. Musci frondosi. Pp. 129-178. In: Warming (ed.). Symbolae ad floram Brasiliae centrales cognoscendam. Videnskabelige Meddelelser fra dansk naturhistoriske Forening i Kjöbenhavn, ser. 3, 19.

Hampe, E. 1874b. Musci frondosi. Pp. 73-141. In: Warming (ed.). Symbolae ad floram Brasiliae centrales cognoscendam. Videnskabelige Meddelelser fra dansk naturhistoriske Forening i Kjöbenhavn, ser. 3, 19.

Hampe, E. 1877. Musci frondosi. Pp. 251-274. In: Warming (ed.). Symbolae ad floram Brasiliae centrales cognoscendam. Videnskabelige Meddelelser fra dansk naturhistoriske Forening i Kjöbenhavn, ser. 3, 24.

Hampe, E. 1879. Enumeratio muscorum hactenus in provinciis Brasiliensibus Rio de Janeiro et São Paulo detectorum. Videnskabelige Meddelelser fra dansk naturhistoriske Forening i Kjöbenhavn 26: 73-164.

Hampe, E. \& Geheeb, A. 1881. Additamenta ad "Enumerationem hactenus in provinciis Brasiliensibus Rio de Janeiro et São paulo detectorum". Flora 64: 337-347, 369-381, 401-416, 433-438.

Herzog, T. 1927. Zwei Bryophyten Sammlungens aus SüdAmerika. Hedwigia 67: 249-268.

Hornschuch, C.F. 1840. Musci. Pp. 1-100. In: C.F. Martius (ed.). Flora Brasiliensis enumeratio plantarum in Brasilia hactenus detectarum quas suis aliorumque botanicorum studiis descriptas et methodo naturali digestas partim icone ilustratas 1(2).

Luetzelburg, A. 1923. Estudos botânicos do Nordeste. Inspetoria Federal de Obras contra Seccas. v. 3: 1-283 (Bryophyta, 232-238).

Magill, E.R. (ed.). 1990. Glossarium Polyglottum Bryologiae. A multilingual glossary for bryology. Monographs in Systematic Botany from the Missouri Botanical Garden 33: 1-297.

Müller, C. 1856. Symbolae ad synopsim muscorum. Botanische Zeitung 14: 415-421, 436-440, 455-459.

Müller, C. 1859. Supplementarum novorum ad synopsis muscorum. Botanische Zeitung 17: 197-198, 214-215, 246-248.

Müller, C. 1898. Bryologia Serrae Itatiaiae. Bulletin de L'Herbier Boissier 6: 18-48.

Müller, C. 1900. Symbolae ad bryologiam Brasiliae et regionorum vicinarum. Hedwigia 39: 235-289.

Müller, C. 1901. Genera Muscorum Frondosorum: i-vii + $1-474$. 
Oliveira-e-Silva, M.I.M.N. \& Yano, O. 1998. Thamniopsis stenodictyon (Sehnem) Oliveira-e-Silva \& Yano, comb. nov. Bradea 8: 81-84.

Oliveira-e-Silva, M.I.M.N. \& Yano, O. 2000. Musgos de Mangaratiba e Angra dos Reis, Rio de Janeiro, Brasil. Boletim do Instituto de Botânica 14: 1-137.

Projeto Flora do Estado do Rio de Janeiro: Bases para o Uso Sustentável da Diversidade Vegetal. 2002 (inédito).

Schäfer-Verwimp, A. 1989. New or interesting records of Brazilian bryophytes, II. The Journal of the Hattori Botanical Laboratory 67: 313-321.

Schäfer-Verwimp, A. 1992. New or interesting records of Brazilian bryophytes, III. The Journal of the Hattori Botanical Laboratory 71: 55-68.

Schiffner, V. \& Arnell, S. 1964. Ergebnisse der botanischen Expedition der kaiserlichen Akademie der Wissenschaften nach Südbrasilien 1901. II. Hepaticae. Österreichische Akademie der Wissenschaften, Mathematischenaturwissenschaftlische Klasse. Denkschriften 111: 1-156.
Sehnem, A. 1979. Musgos sul-brasileiros. v. 6. Pesquisas, ser. Bot., 33: 1-149.

Welch, W.H. 1976. Hookeriaceae. North America Flora, Ser.2, 9: $1-133$

Wijk, R. van der; Margadant, W.D. \& Florschütz, P.A. 1959-1969. Index Muscorum. I-V. Regnum Veg. 17, 26, 33, 48, 65. Utrecht, International Association for Taxonomy.

Yano, O. 1981. Checklist of Brazilian mosses. The Journal of the Hattori Botanical Laboratory 50: 279-456.

Yano, O. 1989. An additional checklist of Brazilian bryophytes. The Journal of the Hattori Botanical Laboratory 66: 373-434.

Yano, O. 1995. A new additional annoted checklist of Brazilian bryophytes. The Journal of the Hattori Botanical Laboratory 78: 137-182.

Yano, O. 1996. A Checklist of the Brazilian Bryophytes. Boletim do Instituto de Botânica 10: 47-232. 